\title{
Evaluation of brain lesions in patients after coronary artery bypass grafting using MRI with the emphasis on susceptibility-weighted imaging
}

\author{
Ilona Michałowska ${ }^{1}$, Mariusz Ireneusz Furmanek², Elżbieta Smaga ${ }^{3}$, Zbigniew Juraszyński ${ }^{4}$, \\ Tomasz Zieliński ${ }^{5}$, Sylwia Chełstowska ${ }^{6}$, Mariusz Kuśmierczyk ${ }^{7}$, Eugeniusz Szpakowski ${ }^{7}$, \\ Anna Mierzyńska ${ }^{5}$, Jerzy Michał Walecki ${ }^{8}$ \\ ${ }^{1}$ Department of Radiology, Institute of Cardiology, Warsaw, Poland \\ ${ }^{2}$ Radiology and Diagnostic Imaging, Medical Centre of Postgraduate Education, Warsaw, Poland \\ ${ }^{3}$ Independent Clinic of Neurology and Clinical Neurophysiology, Institute of Cardiology, Warsaw, Poland \\ ${ }^{4}$ Allenort Hospital, Warsaw, Poland \\ ${ }^{5}$ Department of Heart Failure and Transplantation, Institute of Cardiology, Warsaw, Poland \\ ${ }^{6}$ Department of Diagnostic Imaging, Center for Children's Health, Warszawa, Poland \\ ${ }^{7}$ Department of Cardiac Surgery and Transplantation, Institute of Cardiology, Warsaw, Poland \\ ${ }^{8}$ Medical Centre of Postgraduate Education, Warsaw, Poland
}

Kardiochirurgia i Torakochirurgia Polska 2015; 12 (1): 1-7

\begin{abstract}
Introduction: Patients undergoing coronary artery bypass grafting $(C A B G)$ are at risk of strokes and neurocognitive disorders.

The aim of the study was to assess the clinical utility of susceptibility-weighted imaging (SWI) MRI in detection of new brain lesions in patients after CABG. We assessed the incidence and types of brain lesions and correlated the data with neurological examinations in groups of patients who underwent on-pump and off-pump CABG.

Material and methods: Patients underwent a neurological examination and MRI before, $6-20$ days after and 6 months after the CABG. Fifty-one patients (43 men, mean age 63.12 years) were analyzed.

Results: Fifteen (29.4\%) patients underwent on-pump CABG, 36 (70.6\%) off-pump CABG. On postoperative scans new lesions were detected in $12(23.5 \%)$ patients. Ischemic lesions (visible on diffusion-weighted imaging [DWI]) were detected in 4 patients, in 6 lesions were visible on SWI, in 1 case lesions were visible on SWI and DWI. Hemorrhagic stroke was observed in 1 patient. In the group of patients who underwent on-pump CABG, new brain lesions were observed in $60.0 \%$ of patients vs. $8.3 \%$ of those who underwent off-pump CABG $(p<0.0001)$; these changes more frequently were multiple $(p<0.0013)$ and located infratentorially $(p<0.0218)$. Lesions visible on SWI were observed only in patients undergoing onpump CABG $(p=0.00005)$. In all patients (except for 1 with stroke), lesions visible in MRI were clinically silent.
\end{abstract}

\section{Streszczenie}

Wstęp: Pacjenci poddawani zabiegowi pomostowania tętnic wieńcowych (coronary artery bypass grafting - CABG) narażeni są na powikłania w postaci udarów i zaburzeń neuropoznawczych.

Celem pracy była ocena częstości i rodzaju zmian występujących w mózgowiu u pacjentów po operacji pomostowania tętnic wieńcowych wykrytych w badaniach rezonansu magnetycznego (RM), ze szczególnym uwzględnieniem obrazowania SWI (susceptibility-weighted imaging), oraz porównanie zmian w ośrodkowym układzie nerwowym u pacjentów operowanych z użyciem krążenia (on-pump CABG) i bez krążenia pozaustrojowego (off-pump CABG).

Materiał i metody: Analizie poddano 51 pacjentów (43 mężczyzn, średnia wieku 63,12 roku). Badania RM oraz neurologiczne wykonywane były przed operacją, 6-20 dni i 6 miesięcy po operacji.

Wyniki: U 15 (29,4\%) pacjentów przeprowadzono operację on-pump CABG, u 36 (70.6\%) off-pump CABG. W badaniach RM wykonanych po operacji u 12 (23,5\%) pacjentów wykryto nowe ogniska; u 4 pacjentów były to ogniska niedokrwienne [widoczne w DWI (diffusion-weighted imaging)], u 6 zmiany widoczne w SWI, u 1 pacjenta zarówno w DWI, jak i SWI. Udar krwotoczny wystąpił u 1 pacjenta. U 60\% pacjentów operowanych on-pump CABG stwierdzono zmiany w mózgu (vs 8,3\% w grupie operowanej off-pump CABG), $p<0,0001$; zmiany te częściej były mnogie $(p<0,0013)$ oraz zlokalizowane podnamiotowo $(p<0,0218)$. Zmiany widoczne w SWI wystę-

Address for correspondence: Ilona Michałowska, MD, Department of Radiology, Institute of Cardiology, 42 Alpejska St., Poland, phone: +48 2234341 68, e-mail: imichalowska@ikard.pl, ilonamich@wp.pl 
Conclusions: The use of SWI enables one to detect lesions occurring in the brain after $C A B G$, invisible in other sequences. On-pump CABG is associated with a greater risk of clinically silent brain damage compared to off-pump CABG.

Key words: $C A B G, M R$, brain changes.

\section{Introduction}

Despite significant development of cardiac surgery and anesthetic techniques, it has not been possible to eliminate neurological complications associated with cardiac surgery. Patients undergoing coronary artery bypass grafting (CABG) are at risk of complications such as strokes, neurocognitive disorders or mental disorders. The mechanism of these complications seems to be multifactorial. Cardiopulmonary bypass (CPB) has long been considered as a major factor of cerebral complications [1]. A significant risk associated with the use of extracorporeal circulation is brain damage caused by micro- and macroemboli, mechanical damage to blood morphotic elements, systemic inflammatory response syndrome (SIRS) or hypoperfusion. However, recent large prospective randomized studies comparing the incidence of neurological events in a group of patients undergoing CABG with and without extracorporeal circulation (on-pump CABG and off-pump CABG) did not confirm a significant decrease in neurological complications in patients operated on without extracorporeal circulation [2-4]. Advanced age, atherosclerotic changes in the ascending aorta, carotid artery stenosis, previous stroke, low left ventricular ejection fraction, atrial fibrillation and atherosclerotic changes in intracranial arteries are mentioned as risk factors for neurological complications [5-8]. There are also conflicting reports concerning the link between cognitive disorders and microembolism occurring during cardiac surgery [9-11]. Magnetic resonance (MR) is a very sensitive diagnostic method in detecting brain damage after cardiac surgery. Different MR imaging techniques, including diffusion imaging (diffusion-weighted imaging - DWI), FLAIR (fluid attenuation inversion recovery), PD images (proton density weighted imaging) and T2 sequences markers, are used to identify brain injury. One of the relatively new sequences used to assess blood vessels and brain tissue is magnetic susceptibility imaging (susceptibility-weighted imaging - SWI), which is a high-resolution 3D echo-gradient technique. Susceptibility-weighted imaging is a source of important information about substances differing significantly in terms of magnetic susceptibility from surrounding structures such as deoxyhemoglobin, intracellular methemoglobin, hemosiderin, iron or calcium salts. Susceptibilityweighted imaging differs from gradient echo (GRE) related susceptibility by using both magnitude and phase infor- powały wyłącznie u pacjentów operowanych on-pump CABG $(p=0,00005)$. U wszystkich pacjentów (z wyjątkiem pacjenta z udarem) zmiany wykryte w MR były nieme klinicznie.

Wnioski: Zastosowanie obrazowania SWI pozwala na wykrycie zmian w mózgu powstałych po CABG niewidocznych w innych sekwencjach. Operacja on-pump CABG wiąże się z większym ryzykiem niemego klinicznie uszkodzenia mózgu w porównaniu z operacją off-pump CABG.

Słowa kluczowe: pomosty aortalno-wieńcowe, rezonans magnetyczny.

mation, and can increase the susceptibility differences, specifically the visibility of hemorrhage.

The aim of this study was to assess the clinical utility of SWI in detection of new brain lesions in patients after CABG. We also assessed the incidence and types of brain lesions in patients after CABG and correlated the data with neurological examinations in groups of patients who underwent on-pump and off-pump CABG.

\section{Material and methods}

The study included 60 people ( 9 women, 51 men, mean age: $63.13 \pm 7.26$ years). Eighteen patients underwent $C A B G$ with use of extracorporeal circulation (on-pump CABG) and in 42 patients the surgery was performed on a beating heart (off-pump CABG). Nine patients were lost to followup postoperatively due to death (3 patients died a few days after the operation in the intensive care unit [ICU]) or refusal to participate further $(n=6)$. Patients underwent a neurological examination, electroencephalography (EEG), Mini-Mental State Examination (MMSE) tests and MR imaging before, 6-20 days after and 6 months after the CABG. Doppler examination of carotid arteries was performed in all patients before CABG.

Fifty-one patients who underwent examinations before and in the early postoperative period were analyzed. After 6 months a full set of examinations was performed in 42 patients ( 6 refused to undergo examinations, 1 patient died during follow-up and 2 patients had pacemakers implanted). Study exclusion criteria were: refusal or inability to understand and sign the informed consent form, stroke within the last 6 months, significant carotid artery stenosis (> 70\%), urgent bypass grafting or simultaneous heart valve implantation, and contraindications for MR.

\section{Neurological examination}

Detailed neurological examinations and assessment of mental state with the MMSE were performed by the same neurologist before and after the surgery. Changes in the neurological condition after the surgery were analyzed based on the neurological examination (the modified Rankin [mRankin] scale and the NIH Stroke Scale [NIHSS] were used) and EEG (visual analysis, routine 10-20 montage including 21 electrodes, different montages - one canal was for ECG) and MMSE. Electroencephalography results were divided into 3 groups: normal, small disseminated changes and se- 
vere generalized changes. Mini-Mental State Examination - a score of 24 or fewer points was considered as mental impairment. At least a four-point drop in the test score of postoperative MMSE in comparison with preoperative results was considered as the deterioration of mental functions.

Magnetic resonance imaging examination was performed using a 1.5T scanner with an 8-channel head coil. Brain MRI examination consisted of conventional T1weighted images (TR $480 \mathrm{~ms}$; TE $11 \mathrm{~ms}$, field of view [FOV], $20 \times 23 \mathrm{~cm}$; matrix $280 \times 320$; slice thickness $5 \mathrm{~mm}$ ), axial fast-spin echo T2-weighted (TR 4750 ms; TE 105 ms; FOV 20 $\times 23 \mathrm{~cm}$; matrix $568 \times 640$; slice thickness $5 \mathrm{~mm}$ ), and axial fluid-attenuated inversion-recovery (TR $9000 \mathrm{~ms}$; TE $89 \mathrm{~ms}$; TI 2500 ms; FOV $20 \times 23 \mathrm{~cm}$; matrix $448 \times 512$; slice thickness $5 \mathrm{~mm}$ ) sequences, DWI (TR 3500, TE $101 \mathrm{~ms}$; b-value 0, 500, 1000, 1500; FOV $23 \times 23 \mathrm{~cm}$; matrix $192 \times 192$; slice thickness $5 \mathrm{~mm}$ ) and SWI (TR $49 \mathrm{~ms}$, TE $40 \mathrm{~ms}$, matrix 220 $\times 320$, slice thickness $1.6 \mathrm{~mm}$, FOV $18.5 \times 23 \mathrm{~cm})$. Preexisting brain abnormalities (e.g. microangiopathy, infarctions) and the appearance of new lesions on postoperative scans were evaluated. Preoperative MRI examinations were classified as: normal, lacunar infarcts, leukoaraiosis, both (lacunar infarcts and leukoaraiosis), or scars of cortical infarcts. Lesions appearing in the postoperative period are referred to as new when they were identified as new in comparison with a pre-operative study. New lesions were classified according to the localization into supratentorial and infratentorial, number (solitary and multiple), the type of changes in MRI: ischemic lesions - causing diffusion restriction (DWI, ADC) and changes visible on SWI.

Doppler examination of carotid arteries was performed using a Philips IU 22 device. The significance of stenosis was assessed based on the color and spectral Doppler. All patients gave their informed consent before participating in the study. The study was approved by the local ethics committee.

\section{Statistical analysis}

Statistical analysis was performed using PASW Statistics 18 (SPSS Inc., Chicago, IL, USA). Continuous variables are presented as mean \pm standard deviation (SD) and compared using 2-tailed, unpaired Student's t-test. The 2-tailed probability value of $p<0.05$ was considered statistically significant. Fisher's test and/or $\chi^{2}$ test were used to test for differences in categorical variables.

\section{Results}

Fifty-one patients (8 women, 43 men, mean age: 63.12 years and age range: $48-79$ years) were analyzed. Fifteen (29.4\%) patients underwent on-pump CABG and 36 (70.6\%) off-pump CABG. The average number of grafted bypasses was $3.09 \pm 1.13$.

\section{Magnetic resonance imaging}

On preoperative MRI scans, $78.43 \%$ of patients showed signs of vascular brain damage (lacunar infarcts in $45.1 \%$, leukoaraiosis and lacunar infarcts in $25.49 \%$, scars of cortical infarction in 7.84\%). No lesions visible on SWI were observed.

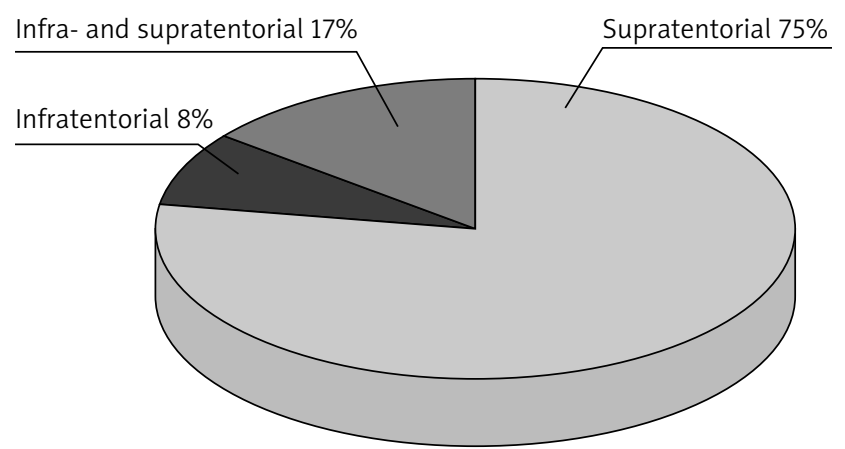

Fig. 1. Localization of brain changes after coronary artery bypass grafting

On postoperative scans (the mean time between the surgery and the examination was $7.41 \pm 2.38$ days) new lesions were detected in 12 (23.5\%) of the 51 patients. Figure 1 presents the localization of lesions.

In the whole group of operated patients (on-pump and off-pump $(A B G)$, multiple, small lesions were observed in 5 patients, and solitary changes were present in 6 patients. Hemorrhagic stroke in the region supplied by the posterior cerebral artery was observed in 1 patient who underwent on-pump CABG. Acute ischemic lesions (visible on DWI) were detected in 4 patients (Fig. 2), in 6 patients new lesions were visible only on SWI (Fig. 3), while in 1 case lesions were visible on SWI and DWI. No correlation was observed between the age of patients (over and under 70 years), hypertension, diabetes mellitus, hypercholesterolemia, and the appearance of postoperative lesions detected by MRI. There was no significant association between the degree of preoperative cerebral lesions and presence of new cerebral lesions in the postoperative period. Characteristics of both groups of patients are presented in Table I.

\section{Comparison of the on-pump and off-pump CABG groups}

There were no significant differences between the patients who underwent on-pump and off-pump CABG in their age or sex distribution, cerebrovascular history, carotid artery stenosis or history of hypertension or diabetes, or in their preoperative MMSE scores, neurological examinations results (mRankin and NIHSS) or MRI abnormalities (lacunar infarcts, leukoaraiosis or previous cortical infarcts). There was a significant difference in prevalence, character and the number of new lesions detected on MRI examination between patients operated on-pump and off-pump (Fig. 4 shows types of new lesions in both groups of patients). In the group of patients who underwent on-pump CABG, changes were observed in $60.0 \%(9 / 15)$ of patients vs. $8.3 \%$ (3/36) who underwent off-pump CABG $(p<0.0001)$; these changes more often were multiple $(p<0.0013)$ and located infratentorially $(p<0.0218)$.

New lesions visible on SWI occurred only in patients who underwent on-pump CABG $(p=0.00005)$ and were located both supratentorially and infratentorially. In MRI examinations performed after 6 months, new small ischemic 

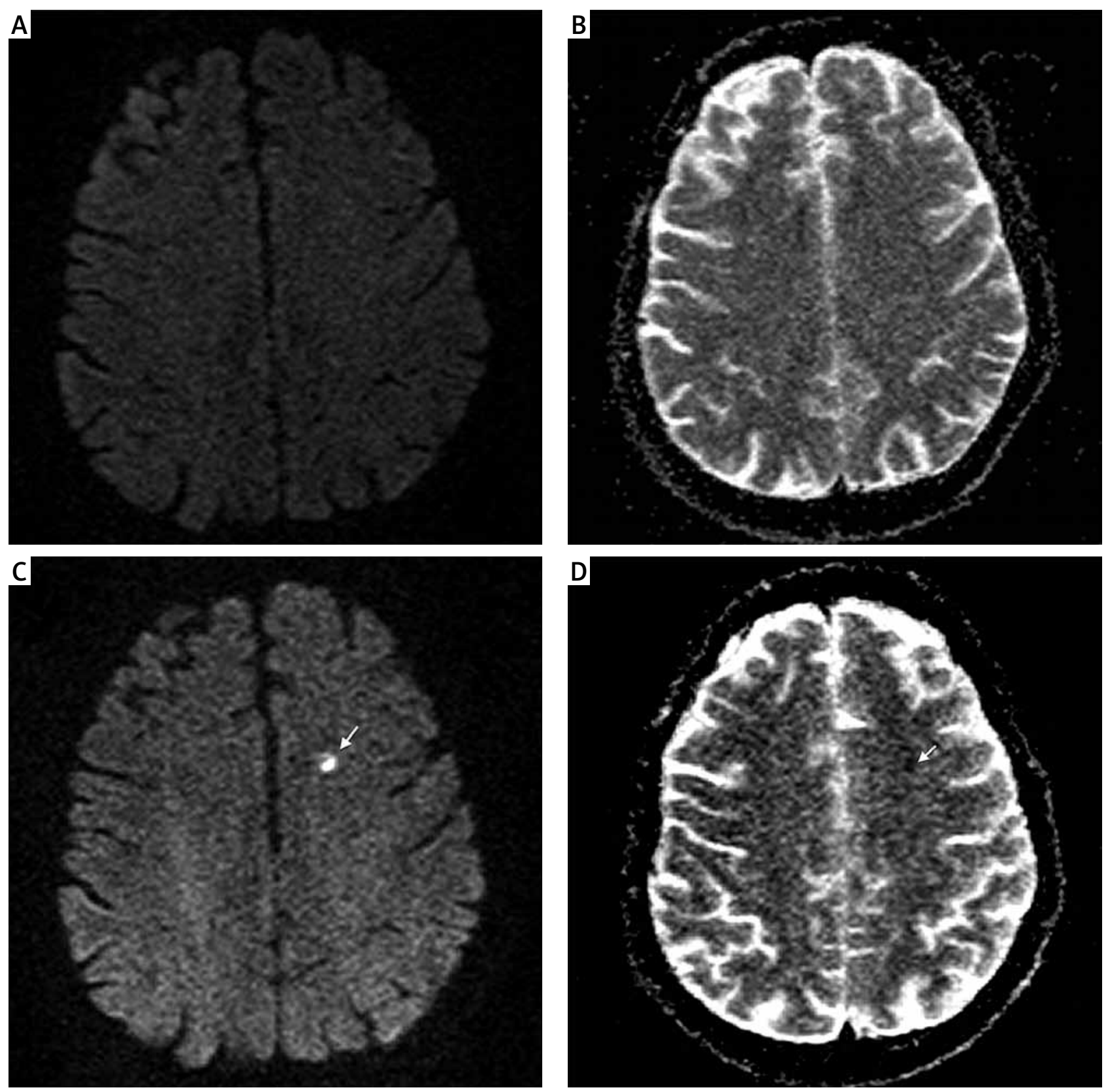

Fig. 2. Diffusion-weighted imaging and $A D C$ images before (A, B) and after coronary artery bypass grafting (C, D). Postoperative scan revealed a focal lesion of diffusion restriction in the white matter of the left hemisphere (arrow)

lesions (not present in early postoperative examination) were detected in 2 patients who underwent off-pump CABG, 1 patient had a stroke during follow-up, and in 1 case resorption of ischemic lesions detected during early postoperative examination was observed. All lesions detected in the early postoperative period on SWI were visible.

In the group of patients operated on on-pump the mean number of bypasses was 3.61 vs. 2.83 in those operated on off-pump $(p<0.05)$.

\section{Neurological examinations}

Preoperative neurological exams (mRankin and NIHSS scale) were normal in all patients except 1 who underwent on-pump CABG. The early postoperative examinations revealed mild neurological symptoms in 2 patients who underwent on-pump CABG (NIHSS scale -3 points). After 6 months improvement in neurological examinations was observed in those patients (NIHSS scale 0 and 1 point). In the whole group, the mean MMSE score was 28.74 preoperatively and 27.8 postoperatively $(p=0.038)$. In the offpump group, the mean MMSE scores were 28.71 preoperatively and 27.91 postoperatively, and in on-pump CABG the mean MMSE scores were 29.07 preoperatively and 28 postoperatively $(p=0.048)$.

In the group of patients who completed the full set of examinations (examination before, in the early stage and 

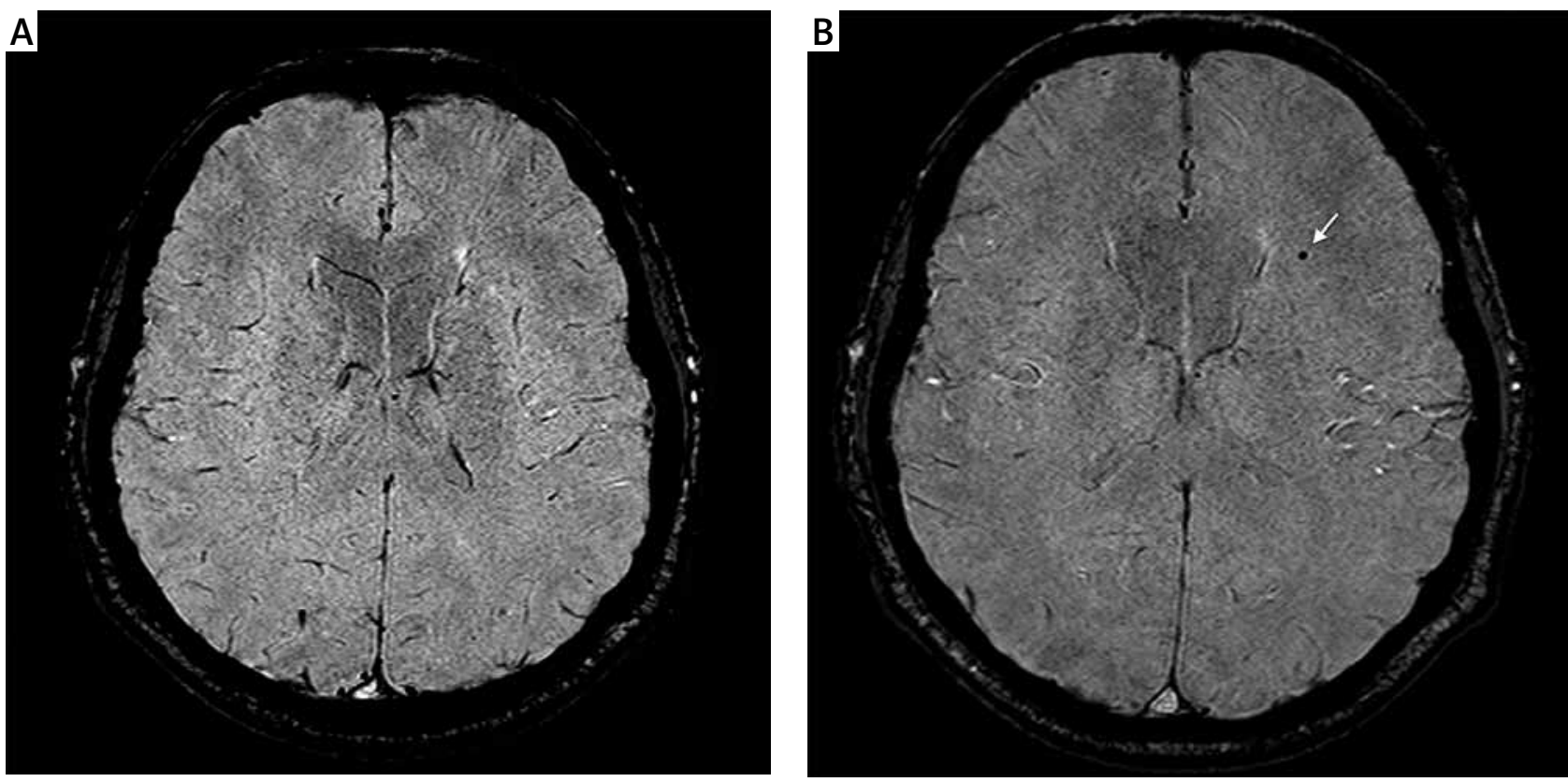

Fig. 3. Susceptibility-weighted imaging MRI before (A) and after coronary artery bypass grafting (B). Postoperative MRI revealed a foca susceptibility effect lesion in the left frontal lobe at the borderline between the internal capsule and the white matter of the frontal lobe (arrow)

6 months after the surgery), normal results of all EEG examinations were obtained in $71.42 \%$.

In 6 patients (2 on-pump, 4 off-pump) in the early postoperative period there was a worsening of EEG findings (more disseminated theta waves within the frequency range from $5 \mathrm{~Hz}$ to $6 \mathrm{~Hz}$ ). In EEG examinations performed 6 months after CABG in 3 cases an improvement of the EEG recording was found (increased frequency of $\alpha$ rhythm more than $1 \mathrm{~Hz}$, improvement of regularity, decreased number of theta waves).

No significant correlation between new brain lesions detected on MRI (both DWI and SWI) and neurological examinations was found. In all patients (except 1 with stroke) lesions visible on MRI examinations were clinically silent.

\section{Discussion}

Coronary artery bypass grafting is connected with the risk of neurological complications, such as stroke or acute encephalopathy $[12,13]$. Neurocognitive impairment oc-

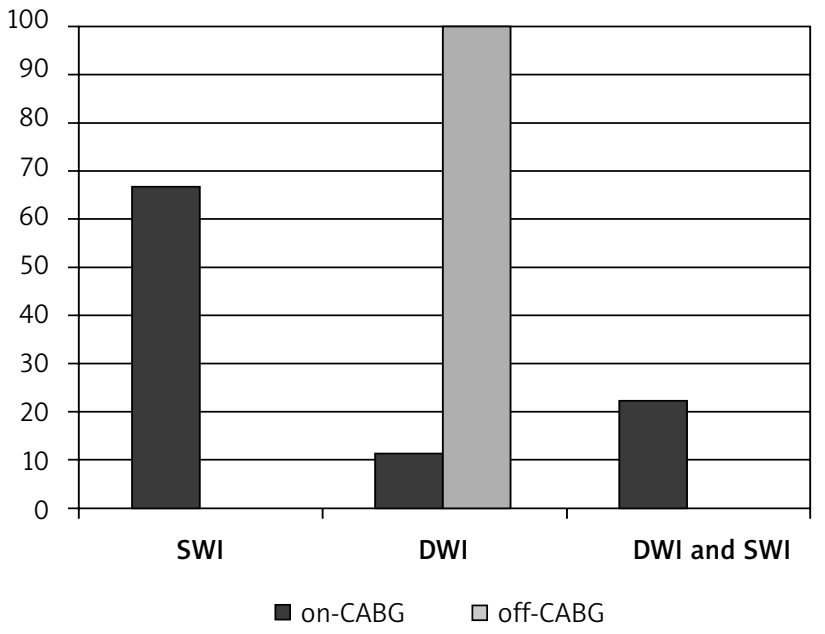

Fig. 4. Graph shows the comparison of brain changes detected by MRI on SWI (susceptibility-weighted imaging) and DWI (diffusionweighted imaging) among patients who underwent on-pump and off- pump coronary artery bypass grafting

Tab. I. Characteristics of patients who underwent off-pump and on-pump coronary artery bypass grafting

\begin{tabular}{lccc} 
Characteristics & On-pump CABG $(n=15)$ & Off-pump CABG $(n=36)$ & 0.156 \\
\hline Age (years) & 62.33 & 63.47 & 0.585 \\
\hline Male/female & $12 / 3$ & $31 / 5$ & 0.08 \\
\hline Hyperlipidemia & $8(53.3 \%)$ & $28(77.8 \%)$ & 0.44 \\
\hline Hypertension & $12(80 \%)$ & $25(69.4 \%)$ & 0.187 \\
\hline Diabetes & $5(33.3 \%)$ & $6(16.6 \%)$ & 0.144 \\
\hline Hospital death & $2(13.3 \%)$ & $1(2.7 \%)$ & 0.0001 \\
\hline Brain changes (number of patients) & $9(60 \%)$ & $3(8.3 \%)$ &
\end{tabular}

$p$ - test of significance, on-pump CABG - coronary artery bypass grafting with the use of cardiopulmonary bypass, off-pump CABG - coronary artery bypass grafting without the use of cardiopulmonary bypass $p<0.05-$ significant 
curs in this group of patients more often, with estimates of $4-90 \%$, whereas the frequency depends on the type of surgery, the group of patients, risk factors and the intervals of testing after surgery [13]. The mechanism of neurological complications in patients after CABG, in particular with the use of extracorporeal circulation, is still not completely clear. The etiology of perioperative stroke is multifactorial. Ischemic strokes secondary to carotid artery stenosis or resulting from cerebral hypoperfusion are rare [14]. Most often, stroke associated with CABG is caused by microemboli. Manipulation of the atherosclerotic aortic arch or gaseous micro-emboli arising from the oxygenator or from the opened heart can cause early embolism [15]. Stroke may occur intraoperatively, early or late, postoperatively. Intraoperative strokes are more often connected with emboli, thrombosis or hyperperfusion [16, 17]. Likosky et al. found that embolic strokes are most frequent, followed by multiple etiologies and hypoperfusion [18]. Magnetic resonance imaging is a very sensitive method used in detecting brain damage. Diffusion-weighted imaging has higher sensitivity in detecting early ischemic changes than computed tomography or conventional MRI images.

Neurological examinations suggest a relatively low risk for ischemic complications of the brain after CABG, but in $25-50 \%$ of patients after CABG new ischemic lesions were detected on DWI MRI [19-21].

In our material, new brain lesions detected on postoperative MRI were observed in $23.5 \%$ of patients, in $9.8 \%$ of cases lesions were visible on DWI, while the majority of new lesions were visible only on SWI. There are a lot of papers about new brain lesions detected on DWI, but we did not find in the available literature any reports about the usefulness of SWI in this group of patients.

Susceptibility-weighted imaging is a source of additional clinical relevant information, complementary to the conventional sequence of MRI. Susceptibility-weighted imaging is a high-spatial-resolution gradient-echo imaging technique which is particularly useful for detecting small amounts of hemorrhage (blood product) or calcium, both of which may be invisible on other MRI sequences. It is also quite sensitive to the presence of other substances such as iron and air.

Many authors have demonstrated considerable usefulness of SWI in assessing microbleeding in diffuse axonal injury, coagulopathies and vascular malformations. T2* weighted gradient-echo MR imaging was the method of choice for detecting cerebral microbleeds because of its sensitivity to the field inhomogeneity caused by hemosiderin deposits [22], but Tong et al. [20] in their work observed 3-6 times higher sensitivity of SWI compared to T2*weighted images of the GE sequence, in detecting the size, number, volume and localization of hemorrhagic changes in diffuse axonal injury [23]. It was also demonstrated that small hemorrhagic foci, invisible in other sequences, could be visualized on SWI.

It seems that the frequency of the appearance of new lesions after CABG should be higher than earlier supposed if the protocol of MRI examination contains the SWI sequence. It is worth noting that in our work, lesions visible on SWI were observed only in patients operated on with the use of extracorporeal circulation, probably depending on the technique of surgery, and may correspond to microhemorrhage foci or emboli caused by calcified atherosclerotic plaques or gaseous. Distinguishing between calcification and blood products is not possible on the post-processed SWI images as both demonstrate signal drop out and blooming. The lesions visible on DWI and SWI, except for 1 patient with stroke, did not cause neurological symptoms. Many authors have concluded that small ischemic lesions detected on DWI-MRI are most often clinically silent [21]. The clinical impact of "silent" ischemic brain lesions after cardiac surgery is debated. Cognitive dysfunction is the most common clinical evidence of brain injury after cardiac surgery.

$A$ relation between ischemic brain lesions detected on MRI after CABG and neurocognitive dysfunction has not been fully proven. Some authors suggest the influence of ischemic lesions on the deterioration of cognitive functions and others report the lack of a relationship [23, 24]. Neurocognitive disorders in the early postoperative period were also observed in patients after non-cardiac surgery, suggesting a relation between these disorders and general anesthesia, not the type of surgery [25]. It is increasingly emphasized that neurological complications have a closer connection with perioperative risk factors (vasogenic changes, patient's age, hyperlipidemia, atrial fibrillation) than the type of surgery, but there are big discrepancies, too.

The limitation of this study is a lack of correlation between brain lesions detected on SWI MRI and neuropsychological examinations, but neurocognitive impairment can be detected only with careful neuropsychological testing by a trained and experienced examiner. A meticulous look for characteristic disturbances in memory, psychomotor speed, executive function, visuo-constructional ability, and ability to concentrate is required [26]. In our work we used only MMSE as a screening test because of the debility of the majority of patients and problems with concentration in the early postoperative period, and it is difficult to reach a conclusion about the correlation between new focal lesions detected on SWI and cognitive dysfunction, as it requires more investigations.

\section{Limitations}

Limitations of this work are the relatively small group of patients operated on with the use of extracorporeal circulation and the lack of randomization of groups of patients; patients were operated on with or without circulation based on the cardiac surgeon's decision.

Another limitation is visual evaluation of EEG and using MMSE as a screening test.

\section{Conclusions}

1. The use of SWI enables one to detect lesions occurring in the brain after cardiac artery bypass grafting, invisible in other sequences. 
2. Cardiac artery bypass grafting using extracorporeal circulation is associated with a greater risk of clinically silent brain damage compared to CABG without the use of extracorporeal circulation.

3. No significant relations were found in patients who underwent on-pump and off-pump CABG between brain lesions detected postoperatively on $M R$ and early and long-term (after 6 months) results of the neurological evaluation.

\section{Acknowledgments}

This work was supported by a grant from the Institute of Cardiology Warsaw (grant no. 2.37.V.09).

\section{Disclosure}

Authors report no conflict of interest.

\section{References}

1. Lee JD, Lee SJ, Tsushima WT, Yamauchi H, Lau WT, Popper J, Stein A, Johnson D, Lee D, Petrovitch H, Dang CR. Benefits of off-pump bypass on neurologic and clinical morbidity: a prospective randomized trial. Ann Thorac Surg 2003; 76: 18-26.

2. Moller CH, Perko MJ, Lund JT, Andersen LW, Kelbaek H, Madsen JK, Winkel P, Gluud C, Steinbrüchel DA. No major differences in 30-day outcomes in high-risk patients randomized to off-pump versus on-pump coronary bypass surgery: the best bypass surgery trial. Circulation 2010; 121: 498-504.

3. Hueb W, Lopes NH, Pereira AC, Hueb AC, Soares PR, Favarato D, Vieira RD, Lima EG, Garzillo CL, Paulitch Fda S, César LA, Gersh BJ, Ramires JA. Fiveyear follow-up of a randomized comparison between off-pump and onpump stable multivessel coronary artery bypass grafting. The MASS III Trial. Circulation 2010; 122 Suppl: S48-S52.

4. Lamy A, Devereaux PJ, Prabhakaran D, Taggart DP, Hu S, Paolasso E, Straka Z, Piegas LS, Akar AR, Jain AR, Noiseux N, Padmanabhan C, Bahamondes JC, Novick RJ, Vaijyanath P, Reddy S, Tao L, Olavegogeascoechea PA, Airan B, Sulling TA, Whitlock RP, Ou Y, Ng J, Chrolavicius S, Yusuf S. Offpump or on-pump coronary-artery bypass grafting at 30 days. N Engl J Med 2012; 366: 1489-1497.

5. Stamou S, Hill PC, Dangas G, Pfister AJ, Boyce SW, Dullum MK, Bafi AS, Corso PJ. Stroke after coronary artery bypass - incidence, predictors, and clinical outcome. Stroke 2001; 32: 1508-1513.

6. Selnes OA, Gottesman RF, Grega MA, Baumgartner WA, Zeger SL, McKhann GM. Cognitive and neurologic outcomes after coronary-artery bypass surgery. N Engl J Med 2012; 366: 250-257.

7. Lee EJ, Choi KH, Ryu JS, Jeon SB, Lee SW, Park SW, Park SJ, Lee JW, Choo SJ, Chung $\mathrm{CH}$, Jung SH, Kang DW, Kim JS, Kwon SU. Stroke risk after coronary artery bypass graft surgery and extent of cerebral artery atherosclerosis. JACC 2011; 57: 1811-1818.

8. Rodriguez RA, Rubens FD, Wozny D, Nathan HJ. Cerebral emboli detected by transcranial Doppler during cardiopulmonary bypass are not correlated with postoperative cognitive deficits. Stroke 2010; 41: 2229-2235.

9. Stroobant N, Van Nooten G, Van Belleghem Y, Vingerhoets G. Relation between neurocognitive impairment, embolic load, and cerebrovascular reactivity following on-and off-pump coronary artery bypass grafting. Chest 2005; 127: 1967-1976.
10. Sun X, Lindasay J, Monsein LH, Hill PC, Corso PJ. Silent brain injury after cardiac surgery: a review. J Am Coll Cardiol 2012; 60: 791-797.

11. Barber PA, Hach S, Tippet LJ, Ross L, Merry AF, Milsom P. Cerebral ischemic lesions on diffusion-weighted imaging are associated with neurocognitive decline after cardiac surgery. Stroke 2008; 39: 1427-1433.

12. Furlan AJ, Craciun AR. Risk of stroke during coronary artery bypass graft surgery in patients with internal carotid artery disease documented by angiography. Stroke 1985; 16: 797-799.

13. Wojtynska R, Rachwalik M, Kustrzycki W. Patomechanisms of central nervous system dysfunction in patients undergoing artery bypass grafting. Pol Przegl Kardiol 2007; 9: 131-136.

14. Hogue CW Jr, Murphy SF, Schechtman KB, Dávila-Román VG. Risk factors for early or delayed stroke after cardiac surgery. Circulation 1999; 100: 642 647

15. Tarakji KG, Sabik JF, Bhudia SK, Batizy LH, Blackstone EH. Temporal onset, risk factors, and outcomes associated with stroke after coronary artery bypass grafting. JAMA 2011; 305: 381-390.

16. Likosky DS, Marrin ChAS, Caplan LR, Baribeau YR, Morton JR, Weintraub RM, Hartman GS, Hernandez F Jr, Braff SP, Charlesworth DC, Malenka DJ, Ross CS, O'Connor GT. Determination of etiologic mechanisms of strokes secondary to coronary artery bypass graft surgery. Stroke 2003; 34 2830-2834.

17. Bendszus M, Reents W, Franke D, Müllges W, Babin-Ebell J, Koltzenburg M, Warmuth-Metz M, Solymosi L. Brain damage after coronary artery bypass grafting. Arch Neurol 2002; 59: 1090-1095.

18. Floyd TF, Shah PN, Price C, Harris F, Ratcliffe SJ, Acker MA, Bavaria JE, Rahmouni H, Kuersten B, Wiegers S, McGarvey ML, Woo JY, Pochettino AA, Melhem ER. Clinically silent cerebral ischemic events after cardiac surgery: their incidence, regional vascular occurrence, and procedural dependence. Ann Thorac Surg 2006; 81: 2160-2166.

19. Restrepo L, Wityk RJ, Grega MA, Borowicz L Jr, Barker PB, Jacobs MA, Beauchamp NJ, Hillis AE, McKhann GM. Diffusion- and perfusion weighted magnetic resonance imaging of the brain before and after coronary artery bypass grafting surgery Stroke 2002; 33: 2909-2915.

20. Tong KA, Ashwal S, Holshouser BA, Nickerson JP, Wall CJ, Shutter LA, Osterdock RJ, Haacke EM, Kido D. Diffuse axonal injury in children: clinical correlation with hemorrhagic lesion. Ann Neurol 2004; 56: 36-50.

21. Kohn A. Magnetic resonance imaging and neuropsychological changes after coronary artery bypass graft surgery. Ann Thorac Surg 2002; 73: S363S365.

22. Greenberg SM, Vernooij MW, Cordonnier C, Viswanathan A, Al-Shahi Salman R, Warach S, Launer LJ, Van Buchem MA, Breteler MM; Microbleed Study Group. Cerebral microbleeds: a guide to detection and interpretation. Lancet Neurol 2009; 8: 165-174.

23. Toner I, Peden CJ, Hamid SK, Newman S, Taylor KM, Smith PL. Magnetic resonance imaging and neuropsychological changes after coronary artery bypass graft surgery: preliminary findings. J Neurosurg Anesthesiol 1994; 6: 163-169.

24. Lamy A, Devereaux PJ, Prabhakaran D, Taggart DP, Hu S, Paolasso E, Straka Z, Piegas LS, Akar AR, Jain AR, Noiseux N, Padmanabhan C, Bahamondes JC, Novick RJ, Vaijyanath P, Reddy SK, Tao L, Olavegogeascoechea PA Airan B, Sulling TA, Whitlock RP, Ou Y, Pogue J, Chrolavicius S, Yusuf S; CORONARY Investigators. Effects of off-pump and on-pump coronary-artery bypass grafting at 1 year. N Engl J Med 2013; 368: 1179-1188.

25. Price CC, Garvan CW, Monk TG. Type and severity of cognitive decline in older adults after noncardiac surgery. Anesthesiology 2008; 108: 18-30.

26. Sun X, Lindsay J, Monsein LH, Hill PC, Corso PJ. Silent brain injury after cardiac surgery: a review: cognitive dysfunction and magnetic resonance imaging diffusion-weighted imaging findings. J Am Coll Cardiol 2012; 60: 791-797. 